\title{
Palindromic rheumatism with rheumatoid nodules: case report with ultrastructural studies
}

\author{
SERGE SCHREIBER, ${ }^{* 1}$ H RALPH SCHUMACHER ${ }^{2}$ AND \\ P VARGHESE CHERIAN ${ }^{2}$
}

From the ${ }^{1}$ Department of Rheumatology, Hospital Erasme, University Libre de Bruxelles, Bruxelles, Belgium; and the ${ }^{2}$ Hospital University of Pennsylvania and Veterans Administration Medical Center; Philadelphia, PA, USA

SUMMARY Rheumatoid nodules developed on the finger tips of a patient with palindromic rheumatism. The patient had no bone cysts or erosions and had no rheumatoid factor. A lighe microscopic and ultrastructural study of a nodule showed a necrotic centre with fibrin, collagen $\frac{0}{2}$ and granular material surrounded by large histiocytes, fibrocytes, lymphocytes, and vessels withadjacent mast cells as has been seen with nodules in classical rheumatoid arthritis (RA). Weeg describe the first immunoperoxidase studies on a rheumatoid nodule and have identified reaction products for immunoglobulins and C3 in perivascular and endothelial cell vacuoles and in theo necrotic centre.

Key words: electron microscopy, immunoglobulins, immunoperoxidase, rheumatoid nodulosis.

Palindromic rheumatism has only infrequently been associated with rheumatoid nodules. In one report three cases of such nodules and large bone cysts were termed 'rheumatoid nodulosis'. We report a case in which typical palindromic rheumatism (PR) was followed by the appearance of rheumatoid nodules in finger pads without chronic synovitis or bone cysts. We give the first ultrastructural description of a nodule associated with PR.

\section{Case report}

A 57-year-old Caucasian man evaluated in La Louviere, Belgium had complained of recurrent arthritis for 10 years. This consisted of bouts of severe pain accompanied by swelling, redness, and

Accepted for publication 20 June 1985

Correspondence to: Dr H Ralph Schumacher, Jr, Professor of Medicine, University of Pennsylvania School of Medicine, Director, Arthritis-Immunology Center, Veterans Administration Medical Center, University and Woodland Avenues, Philadelphia, PA 19104, USA.

*Present address: Service de Médecine Interne, Centre Hospital de Tivoli, 34, Avenue Max Buset, B. 7100 Le Louviere, Belgium. functional impairment, appearing abruptly at irregu lar intervals in one or occasionally in two periphera?. joints and then vanishing without sequellae withire 48 hours at most. Small and large joints werf affected, and the upper limbs were more often involved. In spite of multiple therapeutic attemptis with non-steroidal anti-inflammatory drugs and with colchicine, the painful attacks progressively in creased in severity and in frequency; about $20 \%$ crises had occurred during the last three years. $\frac{D}{0}$

The patient also noted the development over the past six months of pea-sized firm subcutaneous nodules in the pads of the left thumb and the right third finger. One of the nodules had been biopsied and recurred. Light microscopy of thaf nodule showed central fibrinoid necrosis surroundea by a corona of mononuclear cells in a palisade-like manner (Fig. 1). The patient denied any othe complaints, and physical examination between attacks was unremarkable except for the nodules -

Blood and urine uric acid levels were withira normal limits, as were the calcium, phosphorus, anf alkaline phosphatase, the acute phase reactants? haemolytic complement, $\mathrm{C} 3$ and $\mathrm{C} 4$ fractions, renat 


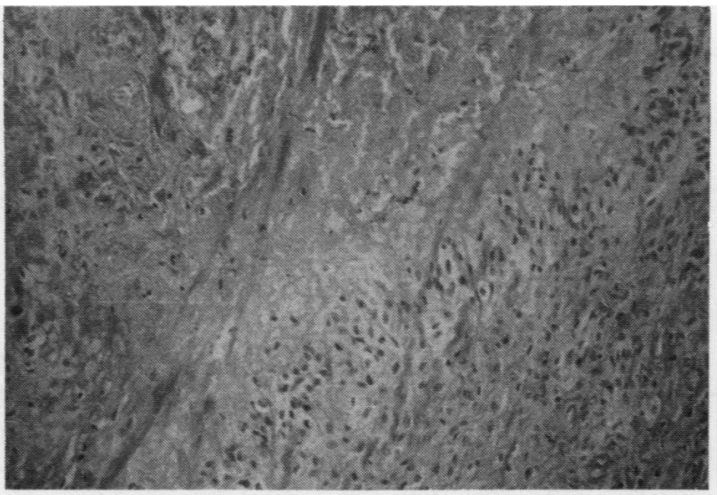

Fig. 1 Central necrosis (upper left) surrounded by palisading mononuclear cells. Light micrograph.

(Haematoxylin-eosin, $\times 40$ ).

function, protein electrophoresis, complete blood count, helper/suppressor lymphocyte ratio, and urine sediment. Rheumatoid factor, antinuclear and anti-DNA antibodies, and circulating immune complexes were repeatedly negative. Cryoglobulin was detected but in too small an amount for quantitative determination. The HLA phenotype was A1, Bw44, B8, Cw4, DR2, DR7. Joint $x$-rays were normal without any sign of erosion, demineralisation, articular or para-articular calcification, or bone cyst. The patient was put on intramuscular gold salt therapy with a dramatic effect: after $335 \mathrm{mg}$ sodium 3-aurothio-2-hydroxypropane-1-sulphonate no new episode of arthritis occurred, and after the completion of a $1500 \mathrm{mg}$ regimen he has remained free of symptoms for 26 months. The nodules have remained unchanged.

\section{Methods}

Another nodule biopsy was performed (after institution of gold therapy) for ultrastructural study. This was processed as previously described for routine electron microscopy (EM) and immuno EM. ${ }^{23}$ For immuno EM endogenous peroxidase activity was blocked by incubating in $3 \% \mathrm{H}_{2} \mathrm{O}_{2}$ in $1 \%$ methanol for 30 minutes. Specimens were incubated in: (a) $100 \mu \mathrm{g} / \mathrm{ml}(\mathrm{mg} / \mathrm{l})$ of either rabbit antihuman IgG (RaHIgM), IgA (RaHIgA), C3 (RaHC3), albumin $(\mathrm{RaHa})$, or fibrinogen (RaHFi); (b) goat antirabbit IgG 1:20 dilution in phosphate-buffered saline (PBS); and (c) peroxidase-antiperoxidase (rabbit) 1:40 dilution in PBS as described by Sternberger. ${ }^{3}$ Specificity controls were used as described before. ${ }^{2}$ For the immunoperoxidase reaction specimens were incubated for $20 \mathrm{~min}$ in a medium containing $10 \mathrm{ml}$ trometamol (TRIS)-HCl buffer at $\mathrm{pH} 7.6$ with $0 \cdot 05 \% \quad 3,3^{\prime}$-diaminobenzidine tetrahydrochloride
(DAB, Sigma); they were then incubated an additional 20 minutes in trometamol buffer containing DAB and $0.05 \% \mathrm{H}_{2} \mathrm{O}_{2}$ for demonstration of enzymatic activity.

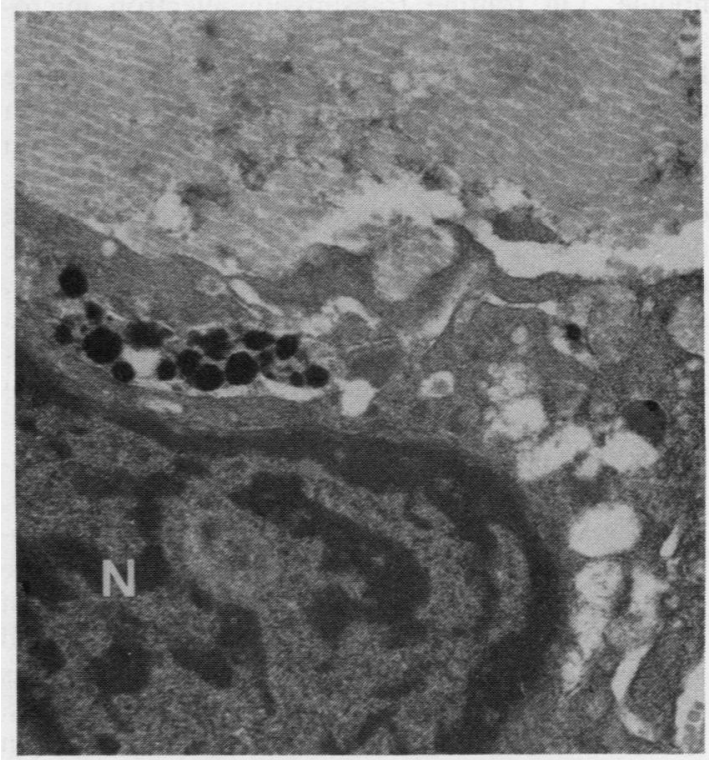

(a)

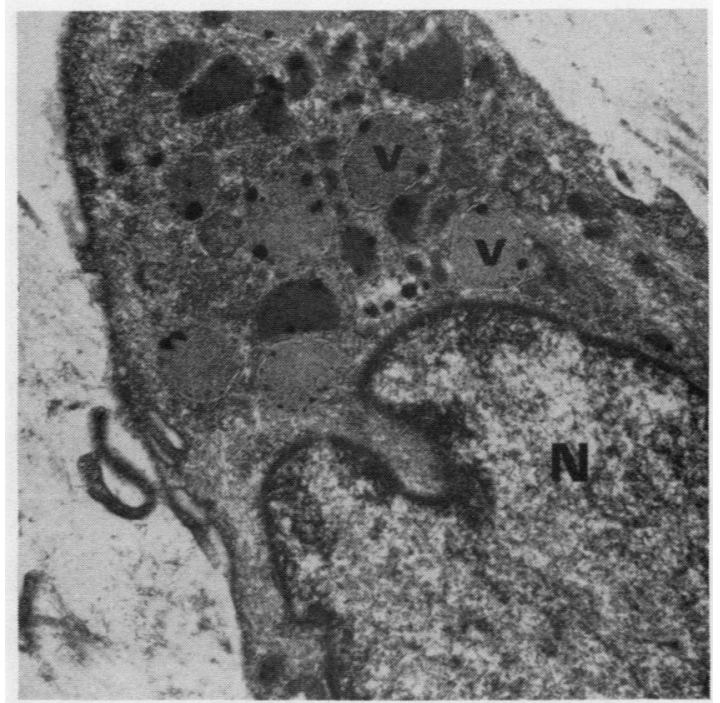

(b)

Fig. 2 (a) Dense reaction product for $I g A$ in vacuoles above nucleus $(N)$ of perivascular mononuclear cell. Electron micrograph. $(\times 24$ 500). (b) Punctate dense reaction product for $C 3$ in vacuoles $(V)$ of perivascular phagocytic cell. Much of the granular material in the C3 containing vacuoles is not stained for $C 3 . N=$ nucleus. Electron micrograph. $(\times 24500)$. 


\section{Results}

Tissue examined by electron microscopy included pieces containing necrotic material and vascular connective tissue apparently from the margin of the nodule. On routine transmission electron microscopy necrotic areas showed cell fragments, fibrin, finely granular material, and collagen. Intact tissue contained essentially normal appearing vessels with only slightly prominent endothelial cells with vacuoles. Some apparent oedema dissociated layers of the basement membranes. No electron dense deposits were seen in the basement membrane areas. There were intact perivascular mast cells, scattered lymphocytes, and some apparent increase in perivascular large histiocyte-like cells and fibrocytes. Many fibrocyte-like cells had large homogeneous lipid deposits.

With immunoelectron microscopy strongly positive peroxidase reaction products labelling for IgG, IgM, $\operatorname{IgA}$, and $\mathrm{C} 3$ were seen in perivascular mononuclear cell vacuoles (Fig. 2). Weaker but definite positive labelling was also seen in vacuoles of venular endothelial cells (Fig. 3). Other unstained granular, vesicular, and membranous material was seen in vacuoles together with the labelled proteins. IgA seemed more likely to label entire vacuoles in some cells. The necrotic areas were not seen in all

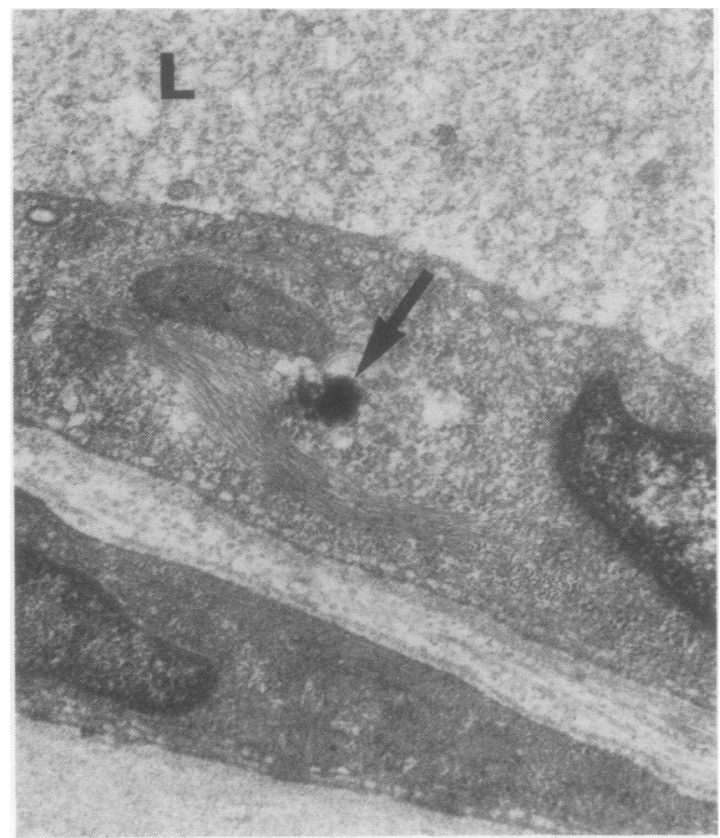

Fig. 3 Fibrinogen reaction product (arrow) in vacuole of vascular endothelial cell. There is also unstained granular protein-like material in the vacuole. $L=$ vascular lumen. Electron micrograph. $(\times 22700)$. portions of the biopsy specimen, and necrotic areas were stained only for $\operatorname{IgA}$ and C3. Positive labelling $\overrightarrow{\vec{F}}$ for both these antigens was seen scattered through- $-\frac{\vec{\sigma}}{\sigma}$ out the granular material. Control sections showed등 occasional very small reaction products that in no instance could be confused with the specific $\widehat{\varnothing}$ reactions.

\section{Discussion}

In 1944 Hench and Rosenberg described a clinical $\overrightarrow{\vec{\omega}}$ pattern of recurrent arthritis that they named palindromic rheumatism (PR). ${ }^{4}$ This consisted of 'multiple afebrile attacks of acute arthritis, periar-i thritis, and sometimes para-arthritis, with pain, -swelling, redness, and disability, generally of only one but sometimes more than one small or largeo joints in an adult of either sex'. Outstanding features were the very rapid onset and disappearance of the bouts, their recurrence at irregular intervals, the absence of roentgenographic abnormalities, and the absence of functional or deforming residues.

Since then there have been many reports of $\overrightarrow{0}$ patients with comparable features. In a large serieso of patients with typical PR followed up for at leasto five years Ward and Okihiro found that more than aO third eventually developed rheumatoid arthritis (RA). ${ }^{5}$ This order of magnitude was latero confirmed. $^{6-9}$ The time period for the palindromico pattern to evolve into frank RA has been as long as 20 years. $^{9}$

Although the absence of subcutaneous nodules has been one of the suggested clinical criteria for diagnosing PR, ${ }^{8}$ Hench and Rosenberg found transient subcutaneous nodules in three out of their original 34 patients with PR. When biopsy was:possible only non-specific inflammatory changes 3 . were observed. ${ }^{4}$ In the subsequent studies of patients with PR such nodules whenever noted were also described as of short duration except when theo disease had already evolved into frank RA. ${ }^{5-10}$ Fascinating cases described by Bywaters in $1949^{1}$ had palindromic features, classical rheumatoid nodules, including some in finger pads, and paras articular cysts and erosions.

In 1975 Ginsberg et al. reported on a seropositive patient with typical PR who presented multipleo subcutaneous nodules and cyst-like bony radio lucencies. ${ }^{1}$ Biopsy of one nodule from a finge showed a necrobiotic centre surrounded by prolifer $\stackrel{?}{?}$ ating fibroblasts and histiocytes arranged in pali- 0 sades. They found three previously published accounts of similar patients with nodules and the same radiological features, two of whom had palin $\stackrel{\vec{D}}{ }$ dromic attacks, and called this 'rheumatoid nodulo응 sis' (RN). Recently Kaye et al. ${ }^{12}$ described four 
seronegative patients with subcutaneous nodules; one had palindromic attacks. Thirteen patients culled from their experience and the literature fit in a proposed classification as group IIA, which was defined as the association of rheumatoid nodules with musculoskeletal complaints and minimal or no chronic synovitis. Some of these patients in fact had a palindromic syndrome. Radiographic cyst-like lesions were present in all but one patient, and rheumatoid factor was found in all cases tested except in their own patient. All were male patients with ages at onset ranging from 24 to 52 years. A 70-year-old woman described by Dreyfus and Daupliex $^{13}$ and case 2 of Herzer's series ${ }^{14}$ also fell into this category. Our patient seems similar to patients in this group. He suffered typical palindromic bouts of arthritis for 10 years without chronic synovitis or systemic illness. Subcutaneous lumps then appeared which under optical microscopy showed changes characteristic of rheumatoid nodules. In contrast with most other cases, however, there was no rheumatoid factor in his serum and no significant roentgenographic findings.

The mechanisms for disease in palindromic rheumatism are not known. An unidentified cryoglobulin was detected in the serum of our patient, but the significance of this has to be weighed cautiously: this positive finding was made during an asymptomatic phase of the disease and several other determinations have been negative thereafter. Previous studies and study in our patient have shown no decreases in serum complement levels. ${ }^{9} 10$ Thompson did report circulating immune complexes detected by a Clq binding assay in four of 19 patients. ${ }^{10}$ In an ultrastructural study of synovial biopsy specimens from patients with PR who later developed definite or classical RA one of us (HRS) showed dramatic microvascular lesions, large amounts of cellular debris, and electron dense deposits in vessel walls, suggesting the possible involvement of immune complexes. ${ }^{15}$ Immunoelectron microscopy of the nodule in our patient also gave some clue to the possible participation of immune complexes by the demonstration of immunoglobulins and complement in vacuoles of vascular endothelial cells and perivascular histiocyte-like cells. There were no deposits in the vessel wall interstitium.

The ultrastructure of rheumatoid nodules has received little study and no previous immunoelectron microscopy. Cochrane et al. ${ }^{16}$ in the first EM description of rheumatoid nodules emphasised the presence of cell debris, collagen and reticulin fibres, and non-collagenous filaments in the necrotic centre. Hashimoto et al. ${ }^{17}$ also described cell debris, collagen, granular and fibrin-like fibrillar material in the nodule centre surrounded by histiocytes and fibroblasts. Lipid was prominent in histiocytes. Gieseking $^{18}$ noted similar findings in the necrotic area, but dense deposits of granular material were suggestive of immune complexes. He also noted lipid in the nodule wall and considered that many cells in the wall seemed to be of vascular origin. We noted a number of similar findings in our patient with PR. The composition of the necrotic area and the lipid deposits seem to be identical to those of previous reports.

\section{References}

1 Ginsberg M H, Genant H K, Yu T F, McCarty D J. Rheumatoid nodulosis. An unusual variant of rheumatoid disease. Arthritis Rheum 1975; 18: 49-58.

2 Cherian P V, Schumacher H R. Immuno-electron microscopic characterization of intra-cellular inclusions in synovial fluid cells of patients with rheumatoid arthritis. Ultrastruct Pathol 1983; 5: $15-27$.

3 Sternberger L A. Immunocytochemistry. 2nd ed. New York: Wiley, 1979.

4 Hench P S, Rosenberg E F. Palindromic rheumatism. Arch Intern Med 1944; 73: 293-321.

5 Ward L E, Okihiro M M. Palindromic rheumatism: a follow up study. Arch Interamer Rheumatol 1959; 2: 208-9.

6 Mattingly S. Palindromic rheumatism. Ann Rheum Dis 1966; 25: 307-19.

7 Bywaters E G L, Ansell B. In: Copeman, W S C, ed. Textbook of rheumatic diseases. 4th ed. Edinburgh and London: Churchill Livingstone, 1970: 524.

8 Williams M H, Sheldon P J H S, Torrigiani G, Elsen V, Mattingly S. Palindromic rheumatism: clinical and immunological studies. Ann Rheum Dis 1971; 30: 375-80.

9 Wajed M A, Brown D L, Currey H L F. Palindromic rheumatism: clinical and serum complement study. Ann Rheum Dis 1977; 36: 56-61.

10 Thompson B, Mohammed I, Holborow E J, Currey H L F. Palindromic rheumatism. II. Failure to detect circulating immune complexes during acute episodes. Ann Rheum Dis 1976; 38: 822-6.

11 Bywaters E G L. A variant of rheumatoid arthritis characterized by recurrent digital pad nodules and palmar fasciitis, closely resembling palindromic rheumatism. Ann Rheum Dis 1949; 8: 1-30.

12 Kaye B R, Kaye R L, Bobrove A. Rheumatoid nodules: review of the spectrum of associated conditions and proposal of a new classification, with a report of four seronegative cases. Am J Med 1984; 76: 279-92.

13 Dreyfus P, Daupliex D. La nodulite rhumatoid. A propos d'un cas. Revue de la littérature. Rev Rhum Mal Osteoartic 1981; 48: 441-6.

14 Herzer P, Sholz S, Fuessl H S, Schattenkirckner M. Rheumatoid nodules without rheumatoid arthritis. Rheumatol Int 1982; 2: $183-7$.

15 Schumacher H R. Palindromic onset of rheumatoid arthritis. Clinical, synovial fluid, and biopsy studies. Arthritis Rheum 1982; 25: 361-9.

16 Cochrane W, Davies D V, Dorling J, Bywaters E G L. Ultramicroscopic structure of the rheumatoid nodule. Ann Rheum Dis 1964; 23: 345-63.

17 Hashimoto K, Yamanishi Y, Dabbous M K, Maeyens E. Collagenase activity in rheumatoid nodules. Ultra-structural in vivo/in vitro studies. Acta Dermat Venereol (Stockh) 1973; 53: 439-48.

18 Gieseking R. Das feinmikroskopische Bild des Rhumatismus Nodosus. Beitr Pathol Anat 1969; 138: 292-320. 